\title{
Motivation toward English language learning of students in secondary and high schools in education service area office 4, Saraburi Province, Thailand
}

\author{
Nakhon Kitjaroonchai \\ Faculty of Arts and Humanities, Asia-Pacific International University, Saraburi Province, Thailand \\ Email address: \\ nakhon@apiu.edu
}

\section{To cite this article:}

Nakhon Kitjaroonchai. Motivation Toward English Language Learning of Students in Secondary and High Schools in Education Service Area Office 4, Saraburi Province, Thailand. International Journal of Language and Linguistics. Vol. 1, No. 1, 2013, pp. 22-33.

doi: 10.11648/j.ijl1.20130101.14

\begin{abstract}
This study aimed to investigate the English language learning motivation level of secondary and high schools students in Saraburi Province, and significant differences between the learning motivation of students with high academic achievement and that of other learners. A modified 20-item motivational survey adapted from Gardner's (1985) Attitude/Motivation Test Battery (AMTB) was administered to 266 secondary and high school students in Education Service Area Office 4, Saraburi Province. The study results indicated that the students had high levels of motivation - both integrative and instrumental - to learn the English language, albeit their instrumental motivation slightly outperformed their integrative motivation. The study also showed that there was a significant difference $(\mathrm{P}$-Value $=0.007$ ) at the level of 0.01 between the learning motivation of students with high academic achievement (GPA $\geq 3.20)$ and that of other peers (GPA $\square 3.20)$.
\end{abstract}

Keywords: Motivation, English Language Learning, Learning

\section{Introduction}

The presentation of the Cebu Declaration on the Acceleration of the Establishment of an ASEAN Community by 2015 at the $12^{\text {th }}$ ASEAN Summit in January 2007 saw the strengthening of member countries' political security, economy, and cultural value. Sharing this vision, identity, and a sense of community with other member countries, the Thai government has been actively gearing its commitment to achieve the roadmap for ASEAN 2015 (ASEAN Secretariat, 2009). According to Pitsuwan, ASEAN Secretary General for 2008-2012, Thailand is fully aware of the ASEAN Community 2015 (Krobkruakao, 2012). To assist the nation towards this goal, the Ministry of Education has mandated that the education sectors throughout the nation are to prepare their students for ASEAN Community 2015 (ASEAN Curriculum Sourcebook, 2012). Thailand's English Speaking Year 2012 program, initiated by Former Education Minister Woravat Auapinyakul was officially launched on December 26, 2011, to help achieve this goal. Schools throughout the nation are thus encouraged to set aside one day a week for students to use English inside and outside their classrooms. According to Former Education Minister Worawat, English must play a key role in communication for Thais and it will be a major language spoken in the ASEAN member countries besides the other regional languages. Chinaworn, another former Education Minister, stated: "Thai people of the new generation must be able to communicate with other people in ASEAN and world communities in English. ... in order to successfully carry out the plan it is necessary to have foreign teachers from countries using English as the mother language for all schools for Mathayom 4-6 level (grades 10-12)" (Bangkok Post, October 7, 2010). The Office of Higher Education Commission urges its college students to develop their English competency to the highest potential not only for career opportunities and they should be able to compete with rivals from other ASEAN member countries at international arenas when mobilization of liberalized labor market and free trade are constructed after the AEC 2015 debuts. Among the necessary working skills, English language proficiency is one of the most important, as language is a fundamental part of workers' human capital. According to Wuthiya and Kanokwan (2012) English language has always been one of the weakest features of Thai skilled labor and it can be a decisive factor for any employment opportunities of workers. Meanwhile, the 
American Chamber of Commerce in Thailand (AmCham) notes that foreign companies are currently forced to promote English proficient employees to higher positions over non-English speaking employees with qualifications. The forming of ASEAN Community 2015 will allow the flow of foreign investments in the region and the expansion of career opportunities for the skilled labor in the Thai labor market. It becomes an immense challenge for the Thai laborers to acquire English language proficiency and other work skills needed for employment and career promotion (Biggs, 2012).

Many stakeholders are involved in this new challenge, especially those in the education arena. Teaching and learning approaches need to be reassessed in order to maximize the learning process. In learning, motivation is regarded as a key component for language achievement (Gardner, 1985; Dornyei \& Otto, 1998; Brown, 2000; Spolsky, 2000; Elyildirim \& Ashton, 2006). Hence, understanding English language learners' motivation to learn English in relation to the forming of ASEAN Community 2015 will provide stakeholders with a working knowledge on how to elevate English language proficiency.

\section{Objective of This Study}

This study investigates the English language learning motivation level of students in secondary and high schools in Education Service Area 4, Saraburi Province, Thailand.

\section{Research Questions}

1. What is the level of the students' motivation for English language learning?

2. What types of motivation (integrative or instrumental) could be the primary source of the students' motivation for learning English?

3. What is the level of students' motivation of English language learning as it relates to the ASEAN Community?

4. Is there any significant difference between learning motivation of high academic achievers $(\mathrm{GPA} \geq 3.20)$ and the learning motivation of other learners?

Hypothesis: High academic achievers have higher motivation to learn English than other learners.

\section{Definition of Terms}

Motivation - the strong desire to learn and the satisfaction experienced in the learning process and the learning outcomes.

Integrative motivation - An interest in learning a foreign language in order to better understand the culture, tradition, and community of the people who speak that language.

Instrumental motivation - An interest in learning a foreign language for pragmatic gains as such passing examinations or university requirements, obtaining a prospective career, or for further education overseas.
High academic achiever - learners whose grade point average (GPA) is equivalent to or above 3.20

\section{Literature Review}

This section provides a review of literature relevant to the scope of the research objectives. The review includes a brief overview of English language learning in Thailand and the theory of motivation proposed by Gardner (1985).

\subsection{English Language Learning in Thailand}

According to the Thai TESOL Association study (Durongphan et al., n. d.), English language has been taught in Thailand for over a century. The English language was first taught in the reign of King Rama III (1824 -1851) by an American missionary who entered the country with the purpose of disseminating Christianity to the Siamese. Later, when King Rama IV (1851-1868) ascended the throne he well perceived the threat of western colonization, so he started to learn English himself in order to communicate and exchange insights with foreign diplomats for the benefit and welfare of the kingdom. English became a prominent foreign language during the reign of King Rama V (1868-1910) during which epoch a vast number of foreign merchants flooded the country for trade and business. The King perceived the critical need for English education for the development of the country as well as diplomatic purposes. He sent royal princes and officers to be educated in Europe to develop the nation after the completion of their studies. During the reign of King Rama V, the Ministry of Education was founded and more schools were established to provide basic education for commoners. Thus, the knowledge of English enabled the officials to deal with foreign partners in business and commerce as well as learn about modern changes in technology and science. When King Rama V died, King Vajiravudh (King Rama VI) succeeded the throne and during his reign he founded the country's first university called Chulalongkorn University, named after his late father, King Chulalongkorn (Rama V). During his reign, King Rama VI issued the Compulsory Education Act which required all children in the nation aged between four to eight years old to attend school. English was made a compulsory subject after grade 4 (Darasawang, 2007) making it the first compulsory foreign language subject for students at primary, secondary, and high school levels as well as a required subject in the National University Entrance Examination. However, the method of teaching English was rote memorization and grammar translation. With such traditional approaches of teaching and learning students who learnt the language did not find it practical and functional

In the last two decades English language teaching pedagogies have strongly emphasized a communicative approach and learners are expected to apply the acquired language skills in real life situations. However, the English curriculum in the secondary school and university cannot meet the demand for English used in the current workplace. 
The skills used most in the workplace are listening and speaking which are not the focused skills in the Thai tertiary education English curriculum (Wiriyachitra, 2001). According to Hiranyapruek (cited in Wiriyachitra, 2001) Thai graduates are actually highly proficient in technology but because they lack English proficiency they cannot make as much progress in science and technology as the western world. Other obstacles to learning the language include the lack of qualified teachers, class sizes, rote learning and memorization.

Due to the shortage of language teachers, some teachers in the elementary school or secondary school are required to teach English courses despite their inexperience in English education. A survey was carried out in February 2006 in collaboration with the University of Cambridge to gauge the qualification of some 400 Thai teachers of English from over 40 schools representing nearly 80,000 elementary and secondary students. The study showed that over $60 \%$ of the teachers had insufficient knowledge of English and teaching methodology (Kaewmala, 2012).

Most Thai public schools have large classes. This generates sequential challenges such as lesson planning problems, classroom management, instructional ineffectiveness, and noise disturbance. Learners rarely have opportunity to hone their language communicative skills in a large class, and they gradually become passive learners. Passive learners will not master a foreign language despite hours of learning investment in language classroom. To be successful in foreign language learning, learners must keep practicing the language whenever they have a chance both in class and outside since language learning is considered to be a skill (Stern, 1992; cited in Dhanasobhon, 2007).

Thai education remains focused on transferring academic knowledge and on memory-based learning, rather than enhancing students' abilities in acquiring knowledge, creativity, problem solving, and analytical skills despite the fact that learning pedagogy is discouraged (Somwung \& Sujiva, cited in Richmond, 2007). Students may do well in memory-based language tests, but they fail to apply the acquired knowledge in real life situations since memorization is about learning something just because one has been told to without any real interest in them. Learners are not taught how to process and apply that information. Knowing vocabulary and rules of language structures does not guarantee communication ability or language proficiency. Mastering a foreign language involves an alteration in self-image, the adoption of new social and cultural behaviors and ways of being, and it requires learners' motivation (Dornyei, 2001).

All these challenges discussed may have contributed to Thai students having a lower English language proficiency compared to that of other neighboring countries in Asia (EF English Proficiency Index, 2011), and their English performance test score on Ordinary National Educational Test (O- NET) falls far below the standard (NIETS, 2011). This circumstance requires remediation from all educational sectors to boost Thai students' English language education and change techniques or styles of language pedagogies to optimize the learners' language acquisition.

\subsection{The Theory of Motivation}

The Online Oxford Dictionaries define motivation as "a reason or reasons for acting or behaving in a particular way with interest or enthusiasm"(Online Oxford Dictionary, 2013), while Online Business Dictionary explains motivation as an "internal and external factors that stimulate desire and energy in people to be continually interested and committed to a job, role or subject, or to make an effort to attain a goal" (Online Business Dictionary, 2013). In line with Dornyei and Otto (1998, p. 65), Harmer (2007, p. 98) defines motivation as "the dynamically changing cumulative arousal or internal drive in a person that initiates, directs, coordinates, amplifies, terminates, and evaluates the cognitive and motor processes whereby initial wishes and desires are selected, prioritized, operationalized and successfully or unsuccessfully acted out".

Gardner (1985, p. 10) stated that motivation is "the extent to which the individual works or strives to learn the language because of a desire to do so and the satisfaction experienced in the activity." According to Gardner, in order to understand why language learners were motivated, it is essential to understand the learners' ultimate goal or purpose for learning the language. He referred to this as learner's orientation. His theory of second language learning motivation is identified in two distinct orientations; namely, integrative orientation and instrumental orientation, both of which affect foreign language learners in one way or another.

In integrative orientation, learners acquire a foreign or second language to become familiar with members of the language community or to learn about their culture or values. Motivation to learn a second language stems from positive feelings toward the group that speaks that language (Gardner, cited in Dornyei, 2001, p. 50). This type of motivation is defined by Deci and Ryan (1985) as intrinsic motivation in which learners find enjoyment and interest in learning a language with a positive attitude. Integrative orientated learners may even have a desire to increase their affiliation with the target community (Liuoliene \& Metiuniene, 2006) and have a strong desire to learn the language and have optimistic view towards the learning situation, and are more likely to expend more effort and efficiency in learning the language. Likewise, Clement, Dornyei, and Noels (1994), found that learners with high integrative motivation tend to work harder and learn faster than those who have low integrative motivation. Language learners reflect their willingness and interest in social interaction with members of other groups (Gardner \& MacIntyre, 1993, p. 159). Dornyei and Clement (2000) found that integrative motivation is the most powerful general component of language-related affective disposition, determining language choice and level of effort language learners intended to invest in the learning process. Learners with integrative orientation show great interest in English, put 
much effort into English learning, have a high academic self-concept (Cokley, Barnard, Cunningham, \& Motoike, 2001), high self-efficacy (Yi-Guang, Lin et al., 2003), tend to persist when facing challenging tasks, recognize the importance of learning the language and internalize learning into their self-value system (Wang, 2008).

Instrumental orientation or extrinsic motivation refers to the learning of a foreign/second language for pragmatic gains such as passing examinations or university requirements, obtaining a prospective career with lucrative income, or for further education overseas. Gardner et al. (cited in Al-Tamimi \& Shuib, 2009, p.32) defines instrumental motivation as "learning a language because of some more or less clearly perceived utility it might have for the learner." The learner desires to learn the language in order to accomplish some non-interpersonal purpose. He is motivated by external factors such as appraisal, gratification, pledge, or money to compel them towards accomplishment without realizing their genuine interest. They perform mainly for the attainment of a desired external reward. Schools that emphasize grades, tests and competition usually only encourage learners' extrinsic motivation and such a strategy may have an influence on learners' interpersonal purpose or learning progress in the long run (Wang, 2008). According to Wang, instrumental motivation is "a controlled motivation which decreases autonomy and causes external perceived locus of causality (EPLOC)". (Walker \& Deci, cited in Wang, 2008, p. 642) Unlike intrinsic motivation, extrinsic motivation requires a shallow cognitive strategy which negatively affects achievement. Language teachers are discouraged from employing pedagogies which insinuate external factors in class activities. Extrinsic motivation can only be applied when a learners' intrinsic motivation is declining (Lile, 2002).

It may be hypothesized that integrative motivation outperforms the instrumental one in terms of language cognitive persistence and mastery. However, in foreign or second language acquisition both have an impact on learners' motivation one way or another. According to Dornyei (2001), integrative and instrumental motivations are not found to be at the opposite ends of a continuum. They are positively related and both are affectively loaded goals and can produce learning. They both may be in return enhanced by better proficiency and higher achievement in the target language (Dornyei, 1994; 2001). Brown (2007, p. 173) adds that successful classrooms usually incorporate both intrinsic and extrinsic motivation. Wan-er (2008) claimed that although instrumental motivation does not have the same positive function as integrative motivation, it will very often function positively together with integrative motivation in a learner's study. Language teachers must understand the circumstances under which they can use extrinsic motivational strategies without undermining the intrinsic motivation which learners already have, and teachers can safely use extrinsically oriented strategies when their students have absolutely no intrinsic interest in the activities (Spaulding, 1992).

\subsection{Related Studies}

Studies on secondary and high school students' English language learning motivation conducted elsewhere like in China, Kyriacou and Zhu (2008) explored the perception of high school students regarding their motivation towards learning English and their perceived influence on others, and the findings indicate that these students' English learning motivation is dominated by life and career-based reasons rather than integrative reasons. In Dubai, Qashoa (2006) examined students' integrative and instrumental motivation for learning English in UAE state secondary school, and the findings showed that the students have a higher degree of instrumental motivation than integrative one. These students indicated that they learn English because they want to obtain a better job since the labor market offers more higher-paying job for those who are competent in English. In Thailand, Choosri and Intharaksa (2011) investigated the vocational students on the relationship between motivation and their language learning achievement. The findings unveiled a correlation between motivation and these students' English learning achievement. However, the students' instrumental motivation slightly outperformed the integrative one, and they indicated that English is necessary for their future study as well as career opportunity. Kitjaroonchai and Kitjaroonchai (2012) investigated the types of motivation (integrative and instrumental) that Thai English majors at Asia-Pacific International University hold toward learning of English language, and the study results revealed that the students had high levels of integrative and instrumental motivation to learn English and their instrumental motivation was found slightly higher than their integrative motivation.

\section{Research Methodology}

\subsection{Participants}

The sample for this study consisted of 266 students from 10 different secondary and high schools in Education Service Area 4, Saraburi Province. The participants were 50 male and 216 female students aged between $12-19$ years old who participated in the Faculty of Arts and Humanities of Asia-Pacific International University's annual academic services at Kaengkhoi School and at the University for two Sundays.

These students attended the program with an expectation of improving their communication skills. The Basic Education Core Curriculum 2008 requires these students to take at least two English language classes as compulsory subjects at school at each grade level. The English language courses put emphasis on basic language skills; reading, listening, speaking, and writing with different levels of difficulty in order to help students to develop basic communication skills as well as understand the culture of native speakers. 


\subsection{Instrument}

The instrument used in this study was a motivational questionnaire and an open-ended question.

a). The motivational questionnaire was adopted from the questionnaire developed by Gardner's (1985) Attitude Motivation Test Battery (AMTB) with the integrative and instrumental orientation scales. The questionnaire consists of 20 five-point Likert (1932) scale items (on a scale of 1-5, ranging from strongly disagree $=1$ to strongly agree $=5$ ). In regard to the motivational survey, the researchers chose statements that were most suitable for Thai students and the reality of their cultural context.

b) The open-ended question intended to investigate students' English language learning difficulties. They could express the barriers or difficulties which they experience while learning English. This helped the researcher to better understand their perception while facing challenges.

The questionnaire consisted of the following parts (see appendix I):

Part I: General information of respondents: gender, age, year of study, grade point average (GPA). The students' demographic data in this study only served as general information. It was not further analyzed.

Part II: Integrative motivational items $(1,2,7,8,9,13,16$, $17,18)$, and instrumental motivational items $(3,4,5,6,10$, $11,12,14,15,19,20)$ (see appendix I). These questionnaire items were rated on the five-point Likert scale ( $1=$ strongly disagree to $5=$ strongly agree)

It is worthwhile mentioning that the questionnaire items were translated into Thai since these secondary and high school students would better perceive all the questions in Thai rather than in English. The questionnaire items in the Thai version were proofread and edited by a well recognized bilingual translator at the university (see appendix II).

\subsection{Data Analysis Procedures}

The data collected from the questionnaire in this study were computed and analyzed in terms of means and standard deviation by using MINITAB version 16. The additional open-ended question in Part III of this survey form was analyzed quantitatively.

To interpret the mean score for students' motivational level, the researchers adopted the interpreting procedure designed by Best (1981) and Degang (2010) as follows:

Table 1. Interpretation of mean score of motivational levels

\begin{tabular}{clll}
\hline Scale & Mean Range & Motivational Level & Score Range \\
\hline 5 & strongly agree & very high & $4.50-5.00$ \\
4 & agree & high & $3.50-4.49$ \\
3 & moderate & average & $2.50-3.49$ \\
2 & disagree & low & $1.50-2.49$ \\
1 & strongly disagree & very low & $1.00-1.49$ \\
\hline
\end{tabular}

The mean score for each item indicated the level of students' motivation; a high score meant students had high motivation, while a low score meant students had low motivation.

\section{Results and Analysis}

The 266 respondents were 50 male and 216 female students aged between 12- 19 years. They were in different years of study ranging from grades 7 (M.1) to 12 (M.6). Figure A below portrays the percentage of respondents in each year level.

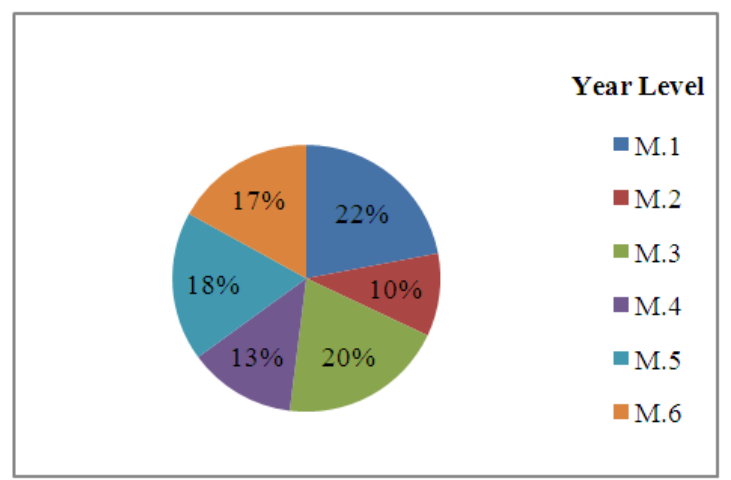

Figure A. Percentage of respondents in each year level

Table 2 below indicates the overall mean score and average mean scores for the two motivational types: integrative and instrumental. The results are presented in average mean scores indicating the motivational levels based on the criteria of Likert (1932), as outlined in Table 1.

Table 2. Overall mean score and average mean scores for integrative and instrumental motivation

\begin{tabular}{lll}
\hline Type of Mean Scores & $\bar{x}$ & $\begin{array}{l}\text { Motivational } \\
\text { level }\end{array}$ \\
\hline Overall mean score & 4.39 & high \\
Average mean score for integrative motivation & 4.22 & high \\
Average mean score for instrumental motivation & 4.51 & very high \\
\hline
\end{tabular}

As shown on the Table 2, the overall mean score stands at 4.39, which is interpreted as 'high' motivation, meaning that these students are highly motivated to learn English.

In comparing the two types of learning motivation: integrative motivation and instrumental motivation, it was found that these students had close to equal integrative and instrumental motivation to learn English with average mean scores of 4.22 and 4.51 , respectively. Their instrumental motivation to learn English was very high and it slightly outperformed their integrative motivation by 0.29 .

These research findings are consistent with motivational studies discussed earlier (Qashoa, 2006; Kyriacou \& Zhu, 2008; Choonsri \& Intharaksa, 2011; Kitjaroonchai \& Kitjaroonchai, 2012).

As seen in Figure B, $48 \%$ of these students had very high level of motivation and $49 \%$ of them had high level of motivation. In other word, $97 \%$ of the students were motivated to learn English, whereas only 3\% had average level of motivation to learn English. None of the participants indicated low motivation to learn the language. Such 
findings imply that these students were motivated to learn English.

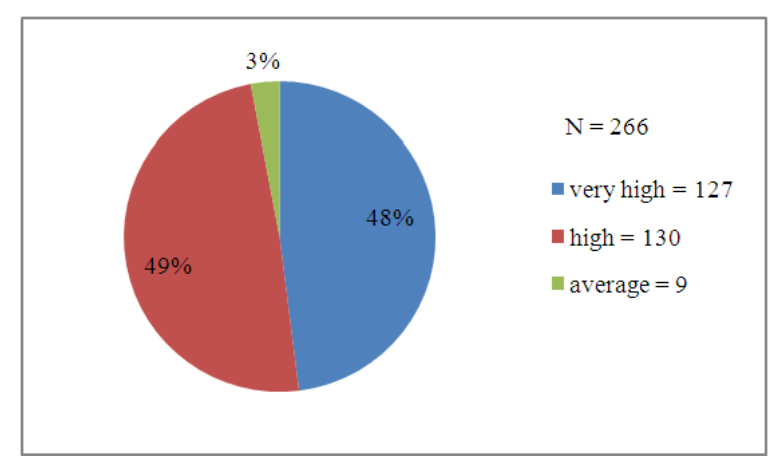

Figure B. Percentage of students' motivation level

The following two tables (Tables 3 and 4 ) outline the 20 question items with their mean scores $(\bar{x})$ and standard deviations (SD).

Table 3. Mean scores and standard deviations of integrative motivation items

\begin{tabular}{|c|c|c|c|}
\hline & Integrative Motivation Items & $\bar{x}$ & SD \\
\hline Q1 & $\begin{array}{l}\text { Studying English is important to me } \\
\text { because I can understand the cultures and } \\
\text { traditions of the ASEAN member } \\
\text { countries. }\end{array}$ & 4.44 & 0.60 \\
\hline Q2 & $\begin{array}{l}\text { Studying English is important to me } \\
\text { because I can understand English stories, } \\
\text { novels, and literature. }\end{array}$ & 4.13 & 0.74 \\
\hline Q7 & $\begin{array}{l}\text { Studying English helps me to better } \\
\text { understand the ways of life of the ASEAN } \\
\text { member countries. }\end{array}$ & 4.42 & 0.62 \\
\hline Q8 & $\begin{array}{l}\text { Studying English helps me to easily make } \\
\text { friends with foreigners }\end{array}$ & 4.63 & 0.58 \\
\hline Q9 & $\begin{array}{l}\text { Studying English helps me to associate } \\
\text { with the neighbors in the ASEAN member } \\
\text { countries and learn about their values and } \\
\text { beliefs. }\end{array}$ & 4.40 & 0.70 \\
\hline Q13 & $\begin{array}{l}\text { Studying English helps me to be } \\
\text { open-minded and friendly like native } \\
\text { English speakers. }\end{array}$ & 4.40 & 0.75 \\
\hline Q16 & $\begin{array}{l}\text { The Americans and British are kind and } \\
\text { cheerful. }\end{array}$ & 4.06 & 0.81 \\
\hline Q17 & I enjoy watching English news and movies. & 3.88 & 0.92 \\
\hline Q18 & $\begin{array}{l}\text { I enjoy reading English books, articles, } \\
\text { newspapers, and magazines. }\end{array}$ & 3.69 & 0.90 \\
\hline
\end{tabular}

A deeper analysis of motivation as outlined in Tables 3 and 4 , brings out some light on the questionnaire which secured the highest mean scores and the ones with the lowest mean scores. There are 4 items, namely Questions 4, 6, 11, and 14 , that had identical mean scores of 4.68 , which is considered the highest score of the questionnaire results. Such mean scores are interpreted as 'very high' motivation (as indicated in the motivational level in Table 1, page 6). All these four items are delineated under instrumental motivation, and they are, studying English can be important for me because it will help me get an ideal job in the future, or make me a more knowledgeable person, or help me to further my studies, or help me when I travel abroad. It can be inferred that these secondary and high school students well perceived English as an important means for their career prospects and a way to enhance their knowledge and prepare them for advanced studies as well as help them to communicate with foreigners when they travel to other countries. The following are three items (Table 5) which secured the lowest mean scores. The items are arranged in the ascending order from the lowest to the highest mean scores:

Table 4. Mean scores and standard deviations of instrumental motivational items

\begin{tabular}{|c|c|c|c|}
\hline & Instrumental Motivation Items & $\bar{x}$ & $\mathrm{SD}$ \\
\hline Q3 & $\begin{array}{l}\text { Studying English can be important for me } \\
\text { because I will be able to communicate with } \\
\text { my neighbors in the ASEAN member } \\
\text { countries. }\end{array}$ & 4.56 & 0.63 \\
\hline Q4 & $\begin{array}{l}\text { Studying English can be important for me } \\
\text { because it will help me to get an ideal job } \\
\text { in } \\
\text { the future. }\end{array}$ & 4.68 & 0.58 \\
\hline Q5 & $\begin{array}{l}\text { Studying English can be important for me } \\
\text { because I will need it for my future career. }\end{array}$ & 4.64 & 0.57 \\
\hline Q6 & $\begin{array}{l}\text { Studying English can be important for me } \\
\text { because it will make me a more } \\
\text { knowledgeable person. }\end{array}$ & 4.68 & 0.53 \\
\hline Q10 & $\begin{array}{l}\text { Studying English can be important for me } \\
\text { because other people will respect me more. }\end{array}$ & 3.87 & 0.93 \\
\hline Q11 & $\begin{array}{l}\text { Studying English can be important for me } \\
\text { because it will help me to further my } \\
\text { studies. }\end{array}$ & 4.68 & 0.53 \\
\hline Q12 & $\begin{array}{l}\text { Studying English can be important for me } \\
\text { because it will help me search for } \\
\text { information and materials in English on the } \\
\text { Internet. }\end{array}$ & 4.53 & 0.67 \\
\hline Q14 & $\begin{array}{l}\text { Studying English is important to me } \\
\text { because it will help me when I travel } \\
\text { abroad. }\end{array}$ & 4.68 & 0.54 \\
\hline Q15 & $\begin{array}{l}\text { Studying English is important to me } \\
\text { because it will help me to achieve at } \\
\text { school. }\end{array}$ & 4.12 & 0.91 \\
\hline Q19 & $\begin{array}{l}\text { I study English diligently because I want to } \\
\text { earn a university degree. }\end{array}$ & 4.12 & 0.91 \\
\hline Q20 & $\begin{array}{l}\text { I study English diligently because it is an } \\
\text { important tool for communication. }\end{array}$ & 4.63 & 0.66 \\
\hline
\end{tabular}

Table 5. The three items which secured the lowest mean scores

\begin{tabular}{llll}
\hline & Items & $\bar{x}$ & SD \\
\hline Q18 & $\begin{array}{l}\text { I enjoy reading English books, articles, } \\
\text { newspapers, and magazines. }\end{array}$ & 3.69 & 0.90 \\
Q10 & $\begin{array}{l}\text { Studying English can be important for me } \\
\text { because other people will respect me more } \\
\text { if I know a foreign language. }\end{array}$ & 3.87 & 0.93 \\
Q17 & $\begin{array}{l}\text { I enjoy watching English news and movies. } \\
\text { Lenos }\end{array}$ & 3.88 & 0.92 \\
\hline
\end{tabular}

Although these three items received the lowest mean scores compared to other questions outlined in the research questionnaire, they do not indicate that these students were less motivated to read English books, articles, or newspaper, or that they enjoy watching English news and movies. The mean scores of these three items still suggest that the students had fairly high integrative and instrumental 
motivation, as defined in Table 1, page 6.

Aside from looking at how motivation is instrumentally or integratively driven, the general perception towards English language learning needs to be analyzed as well. A general overview may reveal the broad disposition towards the English language. This is shown in Table 6.

Table 6. Mean scores and standard deviations of students' motivation of English language learning as it relates to the ASEAN Community

\begin{tabular}{|c|c|c|c|}
\hline & Items & $\bar{x}$ & SD \\
\hline Q1 & $\begin{array}{l}\text { Studying English is important to me } \\
\text { because I can understand the cultures and } \\
\text { traditions of the ASEAN member } \\
\text { countries. }\end{array}$ & 4.44 & 0.60 \\
\hline Q3 & $\begin{array}{l}\text { Studying English can be important for me } \\
\text { because I will be able to communicate with } \\
\text { my neighbors in the ASEAN member } \\
\text { countries. }\end{array}$ & 4.56 & 0.63 \\
\hline Q7 & $\begin{array}{l}\text { Studying English helps me to better } \\
\text { understand the ways of life of the ASEAN } \\
\text { member countries. }\end{array}$ & 4.42 & 0.62 \\
\hline Q9 & $\begin{array}{l}\text { Studying English helps me to associate } \\
\text { with the neighbors in the ASEAN member } \\
\text { countries and learn about their values and } \\
\text { beliefs. }\end{array}$ & 4.40 & 0.70 \\
\hline
\end{tabular}

The four items in Table 6 as shown above are questions related to students' perception toward ASEAN community. These students indicated that they were very highly instrumentally motivated to study English as the language will enable them to communicate with people in the ASEAN member countries $(\bar{x}=4.56)$, and they were highly integratively motivated to learn English in order to understand the cultures and traditions of the ASEAN member countries $(\bar{x}=4.44)$, their ways of life $(\bar{x}=4.42)$, as well as their values and beliefs $(\bar{x}=4.40)$. It can be inferred that these secondary and high school students were highly integratively and instrumentally motivated to learn English for the benefit of the upcoming ASEAN community in which the average mean score for these four items is $(\bar{x}=$ 4.46).

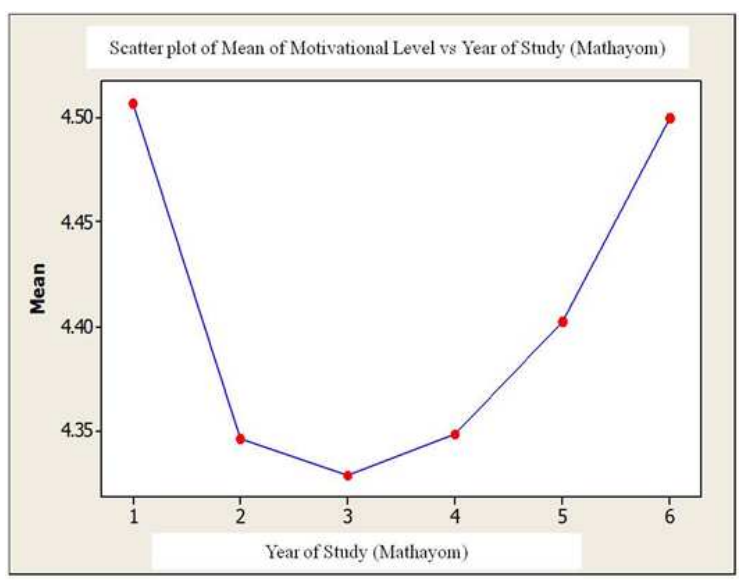

Figure C. Scatter plot of mean of motivational level vs year of study

Since the study engaged students of different class levels ranging from grade 7 (M.1) to grade 12 (M.6), it was worthwhile to analyze the trend of each grade's motivational level. The result of statistical analysis was shown in Figure $\mathrm{C}$ below.

As shown in Figure C, students in Mathayom 1 (grade 7) appeared to have the highest motivational level to learn English among other groups. However, their motivational level started to diminish as they progressed to Mathayom 2 and 3 (grades 8 and 9). Nevertheless, the downhill trend did not remain as students' motivational level gradually increased in subsequent higher grades (Mathayom 4-6). The trend of motivational level and orientation change suggest that when students shift from primary school level to secondary school level, at the first phase their motivation to learn English is very high. This might be due to the fact that they need to adjust themselves to new demands in the higher grade levels. As seen in Figure C, the Mathayom 6 students' motivational level surmounted the other lower levels. This might be due to the fact that these students are rigorously preparing themselves for college education where a greater knowledge and proficiency of English is required. Thus, the determination to achieve these goals may contribute to the subsequent increase in motivational levels.

In spite of being motivated to learn English, students indicated that there are challenges in the language learning process. Their responses to encountered language skills problems in the open-ended question were qualitatively analyzed and the result was shown in Figure D below.

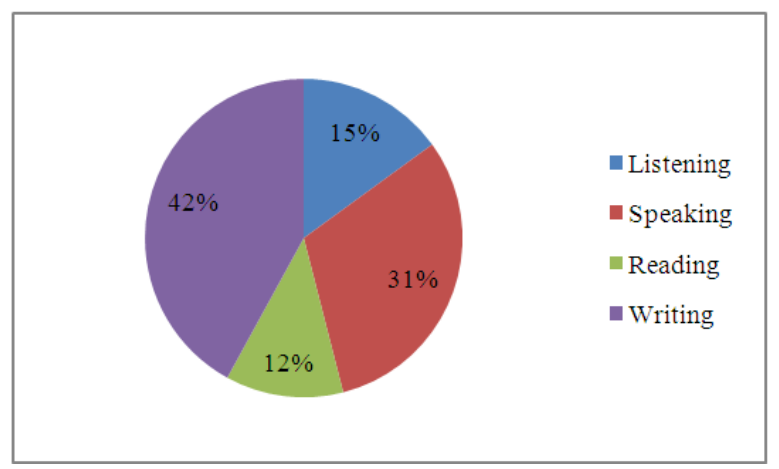

Figure D. Encountered Language Skills Problems

Figure D shows writing skills to be rated the most difficult language skill with the highest percentage of 42 , followed by speaking skills $(31 \%)$, listening skills $(15 \%)$, and reading skills (12\%). According to Watcharapunyawong and Usaha (2012), of the four English skills, writing has been found to be the most difficult for EFL learners to master, especially among the Thai students since writing in a foreign language requires both syntactic and semantic knowledge, and EFL learners seem to be influenced by L1 interference errors. They also found that the interference of L1 appeared frequently in Thai EFL students' English writing errors. Speaking skills was rated the second most difficult skill to acquire, and according to Langlois (cited in Kaewmala, 2012), many Thai students were unable to speak English in real-life situations because they were seldom prodded to do 
so and their culture inclines them to cherish their mother tongue. Although they learn grammar and vocabulary, many students can barely string words together to make a proper sentence or write a simple paragraph. They don't ask questions and end up becoming passive learners, sitting quietly and listening and jotting down notes (Weerawong, cited in Kaewmala, 2012).

The following is an analysis of the significant difference between learning motivation of higher academic achievers $(\mathrm{GPA} \geq 3.20)$ with other learners $(\mathrm{GPA}<3.20)$ by using Two-sample T-Test. The analysis was conducted to respond to research question 4 as outlined on page 2 . The result is shown in Table 7 below.

Table 7. Two-sample T-test for learning motivation of high achievers vs. learning motivation of other learners.

\begin{tabular}{lcccl}
\hline & $\mathrm{N}$ & $\bar{x}$ & $\mathrm{SD}$ & SE Mean \\
\hline $\begin{array}{l}\text { Motivation of high achievers } \\
(\mathrm{GPA} \geq 3.20)\end{array}$ & 122 & 4.458 & 0.335 & 0.030 \\
$\begin{array}{l}\text { Motivation of other learners } \\
(\mathrm{GPA}<3.20)\end{array}$ & 117 & 4.337 & 0.424 & 0.039 \\
\hline
\end{tabular}

Difference $=m u($ Motivation of high achievers $)-m u($ Motivation of other learners)

Estimate for difference: 0.1218

99\% lower bound for difference: 0.0056

$\mathrm{T}$-Test of difference $=0(\mathrm{vs}>)$ : $\mathrm{T}$-Value $=2.46 ; \mathrm{P}-$ Value $=0.007 ; \mathrm{DF}=220$

Table 7 shows that 122 students had a GPA of $\geq 3.20$, and 117 of them indicated a GPA below 3.20. The mean score of language learning motivation of high achievers (GPA $\geq 3.20)$ and other learners (GPA $\square$ 3.20) are 4.45 and 4.33, respectively. From this it can be inferred that the high achievers have a slightly higher motivation than other learners, shown by difference in score of 0.12 . The Two-sample T-Test for learning motivation of high achievers with learning motivation of other learners whose GPA was below 3.20 showed a significant difference $(\mathrm{P}-$ Value $=0.007)$ at the level of 0.01 . Hence, the hypothesis that high academic achievers have higher motivation to learn English than other learners ( $\mu$ High Achievers $>\mu$ Other Learners) is accepted. It appears that the higher GPA students secure the greater motivation they possess to learn English. According to Wang (2008), students' learning motivation and their academic achievement are positively correlated, to which Gardner (2007) adds that students' grades are more highly related to their motivation both integrative and instrumental.

\section{Discussion of the Findings}

This section presents a discussion of the study findings. For ease of reference, the findings are discussed based on the research objectives and research questions. Presented here are the results of the study with regard to 1) The level of students' motivation to learn the English language, and the types of motivation (integrative or instrumental) which could be the primary source of students' motivation toward learning the English language; 2) The level of students' motivation of English language learning as it relates to
ASEAN Community; and 3) The significant difference between learning motivation of high academic achievers $(\mathrm{GPA} \geq 3.20)$ with other learners.

\subsection{The Level of Students'Motivation to Learn the English Language and Types of Motivation}

This study sought to investigate the English language learning motivation of secondary and high schools students in Education Service Area 4, Saraburi Province. The findings showed that students' motivation to learn English language was high. The overall mean score of their motivation level stands at 4.39 out of a five-point Linkert scale. The interpretation of this score is 'high' motivation, as referred to the interpretation of mean score of motivational levels in Table 1, page 6. This implies that these secondary and high school students are highly motivated to learn English. The statistical analysis indicated that these students had both high integrative and instrumental motivation to learn English although the average mean score for their instrumental motivation was a slightly higher than their integrative motivation. Such findings affirm that both integrative and instrumental motivation are primary sources of students' motivation toward learning English despite the fact that their instrumental motivation was just a little greater. The students well perceived English as an essential means for them to get an ideal job, or for them to further their studies, or it makes them more knowledgeable, or it facilitates travel overseas. These items received identical mean scores of 4.68. These findings are consistent with Kyriacou \& Zhu's (2008) study which found that the Chinese high school students participating in their study were dominated by extrinsic reasons such as career aspects and for them to be more cultivated for learning English.

The students realized the importance of learning English in their future careers and their school achievement $(\bar{x}=$ 4.64); knowing English it will help them make friends with foreigners $(\bar{x}=4.63)$. Such findings are in line with Qashoa's (2006) study in which he claimed that in the secondary school in the Eastern Coast of the UEA, those who responded to his study had a higher degree of instrumental motivation than the integrative one, and with Choosri and Intharaksa's (2011) study of Thai vocational college students' motivation and their English learning achievement, in which they found the students' instrumental motivation outperformed their integrative one. The students indicated that they learned English for various practical reasons such as getting a good job, improving future career, continuing higher education, and accomplishing a life goal.

\subsection{The Level of Students'Motivation of English Language Learning Toward ASEAN Community}

The research questionnaire outlined 4 items which are related to issues concerning ASEAN Community, namely Questions 1, 3, 7, and 9. Three of these questions (1, 7, and 9) were under integrative motivation and one question (3) was under instrumental motivation. The average mean score of 
students' motivation of English language learning toward ASEAN Community stands at 4.46 out of a five-point scale, which can be interpreted as 'high' motivation as defined in Table 1, page 6. The students realized the significant role of ASEAN Community, and in order for the country to compete with other ASEAN member countries, the English language proficiency in the country needs urgent updating as it makes up the fundamental parts of human capital and value in the labor market in this era of globalization (Saraithong \& Chanchareonchai, 2012). In the findings, the students asserted that English can be important for them because it would help them to communicate with other people in the ASEAN member countries $(\bar{x}=4.56)$, understand the culture and traditions of the neighboring countries $(\bar{x}=4.44)$, understand the ways of life $(\bar{x}=4.42)$, and learn about their values and beliefs $(\bar{x}=4.40)$. According to Chinnaworn, former Education Minister, the Thai people of the new generation must be able to communicate well in English with other ASEAN and world communities (Bangkok Post, October 7, 2010), while a former Education Minister, Worawat Auapinyakul, initiated a dynamic project called Thailand's English Speaking Year 2012 program. Over the past three years, Thailand has been promoting ASEAN Community through an ASEAN TV channel focusing on news, education, culture, and tourism of ASEAN countries, and educational sectors funded by state agencies have launched various English intensive programs for skilled and unskilled labors to improve their English language proficiency to be ready for the AEC 2015 (Intathep, 2012; Wiriyapong, 2012; the Nation, 2012). Such stimulus in some way or the other echos the students' perception bringing to mind the fact that the phenomena of ASEAN Community will create an impact to their society in the near future. Thus, students highly rated these itemized questions related to ASEAN Community and the importance of English language.

\subsection{Significant Difference between Learning Motivation of High Academic Achievers with other Learners}

The statistical analysis revealed that the students with GPA $\geq 3.20$ in this research defined as high academic achievers, showed a slightly higher motivation than other learners with GPA $\square$ 3.20. The Two-sample T-Test for learning motivation of high academic achievers with learning motivation of other learners resulted in a significant difference $(\mathrm{P}$-Value $=0.007)$ at the level of 0.01 . This implies that students with higher academic achievement have a higher level of learning motivation. The finding is consistent with the findings of Choosri \& Intharaksa (2011) in which they found that students' motivation has a positive relationship with their English learning achievement; with that of Kitjaroonchais (2012) who concluded that both integrative and instrumental motivations are positively associated with an increase in students' academic achievement; and with that of Liu (2007) whose study showed that students' motivation was positively correlated with their English learning achievement.
Despite the slight difference of motivation level between the high academic achievers $(\bar{x}=4.45)$ and other learners $(\bar{x}=4.33)$ found in the present study, it does not mean that other learners had lower motivation than the high achievers because both mean scores of motivation level fall under 'high' motivation as defined in Table 1. In other words, students of both groups proved to have a high level of motivation to learn English regardless of their learning achievement although the ones with higher achievement were slightly higher in terms of the motivation level mean score.

\section{Conclusion}

This study looked into the English language learning motivation level of secondary and high schools students in Saraburi province and the significant difference between learning motivation of students with high academic achievement and that of other learners. The findings of this research showed that these students had high motivation to learn English. They had both high integrative and instrumental motivation to learn the language albeit their instrumental motivation slightly outperformed the integrative one. This could be attributed to the fact that the students felt that learning the English language would help them with future career, education opportunity, and communication in the rapid change of globalization. These students well perceived the importance of the English language for the ASEAN Community. They positively agreed that the language would be a significant means to communicate with other people in the ASEAN member countries and learn about their cultures and traditions, ways of life, values, and beliefs. As the findings disclosed the level of students' motivation of English language learning toward ASEAN Community was high. This was because students were well informed and educated regarding the launching of AEC 2015. In fact, the English camp conducted for these secondary and high school students during which this study survey was administered was a part of the Education Service Area 4's paradigm shift to expose their students to English with foreign teachers many of whom come from ASEAN member countries.

The results of the study indicated that there was a significant difference between learning motivation of students with high academic achievement and that of other peers, notwithstanding that both groups possessed high motivation to learn English. This could be attributed to the fact that these students preferred to attend the English camp that weekend while the rest of their peers chose not to. The possibility could also aim that these students, coming from ten different schools, might be chosen by their teachers on the basis of their class attendance and English proficiency, to represent their respective schools. As the statistical analysis unveiled, 122 students out of 266 (45.86\%) or almost half of them had GPA $\geq 3.20$, and this might be attributed to their high level of motivation in learning the language.

These students rated writing as the most difficult of the 
four language skills to acquire, followed by speaking, listening, and reading, attributable to the fact that, as Watcharapunyawong \& Usaha (2012) noted, the mother tongue (L1) interferes with their second language acquisition since the languages have no identical structures, lexicons, and systems. Hence, the learners' assumption and prediction of language equivalence leads to the errors in production in their second language written outcomes, a major problem which tends to happen in the productive skills of writing and speaking (Hashim, 1999). The perceived language difficulties of these students could be eased by various means of support such as writing workshops, encouraging them to share writing pieces through peer conferences and editing processes, or finding foreign student e-pals to strengthen their writing skills, or conducting writing contests on a regular basis at school. As for speaking drills, students should be stimulated to communicate with their peers in English and make it a habit; language teachers may organize speech contests and train their learners to do more presentations in class to develop their oral communication skills. While productive skills are developed, the receptive skills should not be neglected, as language skills need to be integrated in language classrooms to enhance the learners' actual communication.

In conclusion, this study investigated the English language learning motivation level of secondary and high schools students in Saraburi province and the significant difference between learning motivation of students with high academic achievement and learning motivation of other learners. The study results may not represent similar schools authorized under Office of Basic Education Commission in other regions. However, the researcher is positively confident that the findings are useful and will in one way or another attribute to other related studies and be of value to researchers whose interests dwell on language learning motivation. Further studies regarding learning motivation and other factors contributing to academic achievement should be conducted.

\section{Appendix I}

\section{Questionnaire}

This questionnaire is to survey secondary and high schools students of Saraburi Province's motivation in learning English.

Direction: This questionnaire is divided into 3 parts:

Part I: Student General Information

Part II: Motivational items (integrative motivation and instrumental motivation)

Part III: An open-ended question on students' English language learning skills.

\section{Part I: Student General Information}

Instructions: Please indicate your answer with a tick $(\checkmark)$ in the bracket provided.

1. Gender ( ) male ( ) female

2. Year level ( ) M. $1 \quad$ ( ) M. 2 ( ) M. 3
( ) M.4 ( ) M.5 ( ) M. 6
3. Age
( ) $12-13$ years
( ) 14-15 years

$$
\text { ( ) 16-17 years ( ) 18-19 years }
$$

4. GPA

\section{Part II: Motivational Items (Integrative Motivation and Instrumental Motivation)}

Instructions: Please indicate your choice with a tick $(\checkmark)$ in the column provided which appears most applicable to you. We would urge you to carefully read and give accurate answers since the success of this study depends upon your input.

( 5 = strongly agree, $4=$ agree, $3=$ moderate, $2=$ disagree, 1 = strongly disagree)

\begin{tabular}{l} 
Motivational items \\
\hline 1. Studying English is important to me \\
because I can understand the cultures and \\
traditions of the ASEAN member countries. \\
2. Studying English is important to me \\
because I can understand English stories, \\
novels, and literature. \\
3. Studying English can be important for \\
me because I will be able to communicate \\
with my neighbors in the ASEAN member \\
countries. \\
4. Studying English can be important for \\
me because it will help me to get an ideal \\
job in the future. \\
5. Studying English can be important for \\
me because I will need it for my future \\
career. \\
6. Studying English can be important for \\
me because it will make me a more \\
knowledgeable person. \\
7. Studying English helps me to better \\
understand the ways of life of the ASEAN \\
member countries. \\
8. Studying English helps me to easily \\
make friends with foreigners. \\
9. Studying English helps me to associate \\
with the neighbors in the ASEAN member \\
countries and learn about their values and \\
beliefs. \\
10. Studying English can be important for \\
me because other people will respect me \\
more if I know a foreign language. \\
11. Studying English can be important for \\
me because it will help me to further my \\
studies. \\
12. Studying English can be important for \\
me because it will help me search for \\
information and materials in English on the \\
Internet. \\
13. Studying English helps me to be \\
open-minded and friendly like native \\
English speakers. \\
14. Studying English is important to me \\
because it will help me when I travel \\
abroad. \\
15. Studying English is important to me \\
because it will help me to achieve at \\
school. \\
16. The Americans and British are kind and \\
cheerful.
\end{tabular}




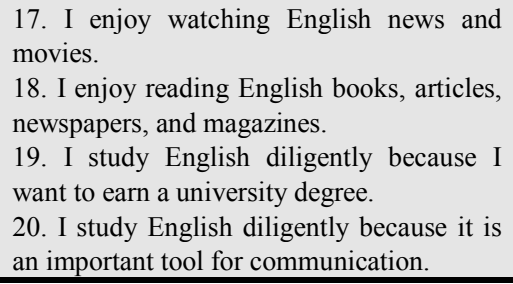

\section{Part III: Open-Ended Question.}

1. What is the most difficulty language skill that you experience while learning English?

\section{References}

[1] Al-Tamimi, A. \& Shuib, M. (2009). Motivation and attitudes towards learning English: a study of petroleum Engineering undergraduates at Hadhramout University of Science and Technology. GEMA Online Journal of Language Studies, Vol. 9(2), pp.29-55. Retrieved May 26, 2013, from: http://www.ukm.my/ppbl/Gema/pp\%2029_55.pdf

[2] ASEAN Curriculum Sourcebook. (2012). Retrieved: November 11, 2012, from : http://www.biotrop.org/attachments/ASEAN_Curriculum_S ourcebook.pdf

[3] ASEAN Secretariat. (2009). Roadmap for an ASEAN Community 2009-2015. Retrieved: November 11, 2012, from: http://www.meti.go.jp/policy/trade_policy/asean/ /dl/ASEANblueprint.pdf

[4] ASEAN Secretariat. (2012). Associations of Southeast Asia Nations: The founding of ASEAN. Retrieved: November 8 , 2012, from: http://www.asean.org/asean/about-asean/history

[5] Bangkok Post. (2010). English to be second language. Retrieved: November 10, 2012, from: http://www.udonmap. com/udonthaniforum/english-to-be-second-language-t18622 .html

[6] Biggs, A. (2012). AEC in 2015? That speels trouble. Retrieved: November 11, 2012, from http://www.bangkokpost.com/learning/education-features/31 8514/aec-in-2015-that-speels-trouble

[7] Brown, H.D.(2000). Principles of language learning and teaching. New Jersey: Prentice Hall.

[8] Brown, H. D. (2007). Principles of language learning and teaching $\left(5^{\text {th }}\right.$ ed.). White Plains, NY: Pearson Education.

[9] Choosri. C. \& Intharaksa, U. (2011). Relationship between motivation and students' English learning achievement: A study of the second year vocational certificate level Hatyai Technical College students. Retrieved: February 10, 2013, from http://sv.libarts.psu.ac.th/conference5/proceedings/ Proceedings $3 /$ article//006.pdf

[10] Clement, R. ; Dornyei, A. ; \& Noels, K.A. (1994). Motivation, self-confidence, and group cohesion in the foreign language. Language Learning, 3. 417-448.

[11] Cokley, K.; Barnard, N.; Cunningham, D.; \& Motoike, J. (2001). A psychometric investigation of the academic motivation scale using a United States sample. Measurement and Evaluation in Counseling and Development, 34, 127-136.
[12] Darasawang, P. (2007). English language teaching and education in Thailand: A decade of change. Retrieved: November 9, 2012, from: http://arts.kmutt.ac.th/crs/Article/English\%20Language $\%$ 20Teaching\%20and\%20Education\%20in\%20Thailand A\% 20Decade $\% 20$ of $\% 20$ Change.pdf

[13] Deci, E.L. \& Ryan, R. M. (1985). Intrinsic motivation and self-determination in human behavior. New York: Plenum.

[14] Dhanasobhon, S. (2007). English language teaching dilemma in Thailand. Kasetsart Educational Review, 22, pp 53-59.

[15] Dornyei, Z. (1994). Motivation and motivating in the foreign language classroom. Modern LanguageJournal, 78, 273-284.

[16] Dornyei, Z. \& Clement, R. (2000). Motivational characteristics of learning different target languages: Results of a nationwide survey. Paper presented at the AAAL convention, Vancouver, Canada. Retrieved November 7, 2012, from: http://www.zoltandornyei.co.uk/uploads/2001-dornyei-clem ent- hi.pdf

[17] Dornyei, Z.,\& Otto, I. (1998). Motivation in action: A process model of L2 motivation. Working Papers in Applied Linguistics (Thames Valley University, London), no. 4: 43-69.

[18] Dornyei, Z. (2001). Teaching and researching motivation. UK, Harlow: Pearson Education.

[19] Durongphan, M. et al. (n.d.) The Development of English Teaching in Thailand: A Rattanakosin Experience.Thai TESOL, Bangkok: Aksorn Charoentat Publishing Company.

[20] [19] EF English Proficiency Index Report (2011). Asia EF EPI Ranking. Retrieved November 5, 2012, from: http://www.ef.com/sitecore/_/ /media/efcom/epi/pdf/EF-E PI-2011.pdf

[21] Elyildirim, S. \& Ashton, S. (2006). Creating positive attitudes towards English as a foreign language. English Teaching Forum. 44, 4: 2-11.

[22] Gardner, R.C. (1985). Social psychology and second language learning: The role of attitudes and motivation.London: Edward Arnold.

[23] Gardner, R.C.\& MacIntyre, P.D. (1993). A student's contributions to second language learning. Part II: Affective variable. Language Teaching. 26: 1-11.

[24] Gardner, R.C. (2007). Motivation and second language acquisition. Porta Linguarum 8, June 2007, 9-22

[25] Harmer, J. (2007). The practice of English language teaching. ( $4^{\text {th }}$ ed. $)$. Essex: Longman.

[26] Hashim, A. (1999). Cross-linguistic influence in the written English of Malay undergraduates. Journal of Modern Language, 12(1), 59-76.

[27] Intathep L. (2012). English for taxi drivers. Retrieved: December 17, 2012, from: http://www.bangkokpost.com /learning/easier-stuff/303846/english-for-taxi-drivers

[28] Kaewmala. (n.d). Thai Education Failures - Part 4: Dismal English-language training. Retrieved: November 6, 2012, from: http://asiancorrespondent.com/78647/thai-educationfailures-part-4-dismal-english-language- education/ 
[29] Kitjaroonchai, N. \& Kitjaroonchai, T. (2012). Motivation toward English language learning of Thai students majoring in English at Asia-Pacific International University. Catalyst, 7 (1), 21-40.

[30] Krobkruakao. (2012).- Retrieved: November 11, 2012, (2012).- Retrieved: November 11, 2012, from:

Retrieved: November 11, 2012, from:

http://www.krobkruakao.com//62838/-.html

.html

[31] Kyriacou, C. \& Zhu, D. (2008). Shanghai pupil's motivation towards learning English and the perceived influence of important others. Educational Studies. Vol. 34, No. 2, May 2008, 97-104.

[32] Lile, W.T. (2002). Motivation in the ESL classroom. The Internet TESL Journal, 8(1). Retrieved November 6, 2012, from: http://iteslj.org/Techniques/Lile-Motivation.html

[33] Liuoliene, A. \& Metiuniene, R. (2006) Second language learning motivation. Santalka. Filologija, Edukologija, T. 14 N. 2: 93-98. Retrieved November 7, 2012, from: http://www.vgtu.lt/upload/filosof_zurn/a liuoliene metiunie ne_filologija_nr2.pdf

[34] Liu, M. (2007). Chinese students' motivation to learn English at the tertiary level. The Asian EFL Journal Quarterly, 9, 126-146.

[35] Nation. (2012). As AEC nears, members work on better English. Retrieved: November 15, 2012, from: http://www.nationmultimedia.com/national/As-AEC-nearsmembers-work-on-better-English- 30178790.html

[36] National Institute of Educational Testing Service (Public Organization) Thailand. (2011). Result of Ordinary National Educational Test 2010 (O-NET). Retrieved May 10, 2012, from: http://www.niets.or.th/up-load-files/ 9/bdaea64f96d90aeca0bb751dc827ca60.pdf

[37] Online Business Dictionary. (2013). Motivation. Retrieved May 23, 2013, from: http://www.businessdictionary.com /definition/motivation.html

[38] Online Oxford dictionaries. (2013). Motivation. Retrieved May 23, 2013, from: http://oxforddictionaries.com / definition/english/motivation

[39] Qashoa, S. H. (2006). Motivation among learners of English in the secondary school in the Eastern Coast of the UAE. Retrieved February 10, 2013, from: http://www.asian-efl journal.com/thesis_Sulaiman_Hasan_Qashoa.pdf

[40] Richmond, J.E. (2007). Bringing critical thinking to the education of developing country professionals. International Education Journal 8(1), 1-29.

[41] Saraithong, W. \& Chanchareonchai, K. (2012). The determinants of new coming workers' English proficiency in the ASEAN Economic Community: A Case of Thai vocational students. Retrieved: November 15, 2012, from: http://www.iises.net/wp-content/uploads/Palermo-papers-Sa raitong.pdf

[42] Spaulding, C. L. (1992). Motivation in the classroom. New York: McGraw-Hill, Inc.

[43] Spolsky, B. (2000). Anniversary article: Language motivation revisited. Applied Linguistics 21(2),157-169.

[44] Wan-er, Z. (2008). Motivation and language learning in the context of China. Sino-US English Teaching, April 2008, 5, (4),(serial no.52).

[45] Wang, F. (2008). Motivation and English achievement: An exploratory and confirmatory factor analysis of a new measurement for Chinese students of English learning. North American Journal of Psychology, 2008, 10, 3, 633-646.

[46] Watcharapunyawong S. \& Usaha S. (2012). Thai EFL students' writing errors in different text types: The interference of the first language. Retrieved March 5, 2013, from http://www.ccsenet.org/journal/index. php/elt/article/ view/23044/14794

[47] Wiriyachitra, A. (2001). English language teaching and learning in Thailand in this decade. Retrieved November 8 , 2012, from: http://www.apecknowledgebank.org/ resources/downloads/English\%20Language\%20 Teach ing\%20and\%20Learning\%20in\%20Thailand.pdf

[48] Wiriyapong, N. (2012). Electronics workforce: Skill upgrade + English needed. Retrieved November 16, 2012, from: http://www.bangkokpost.com/learning/learning-from-news/ 297732/electronics-workforce-skill-

[49] Yi-Guang, L. et al. (2003). College student intrinsic and/or extrinsic motivation and learning. Learning and Individual Differences, 13, 251-258. 